\title{
Studies on the Mechanism of Action
}

\section{of Progesterone in Regulation of}

\author{
the Synthesis of Specific Protein
}

\author{
Bert. W. O’Malley and Winliam L. McGuire \\ From the Endocrinology Branch, National Cancer Institute, National \\ Institutes of Health, Bethesda, Maryland
}

\begin{abstract}
A B STRACT To study the process of hormone action, we have developed an in vitro system utilizing minced oviduct from estrogen-treated chicks incubated in tissue culture medium. Progesterone added to the medium induced synthesis of a specific protein, avidin, that continued for up to $96 \mathrm{hr}$. During this period there was no increase in total oviduct protein, ovalbumin, or lysozyme, which suggests the specificity of the progesterone effect. The induction process was dependent on new protein synthesis, since cycloheximide inhibited the induction completely. Actinomycin D in doses that prevented nuclear RNA synthesis, but not general protein synthesis, inhibited avidin production $70-90 \%$. Avidin synthesis was not affected by 5 -fluorouracil. The rate of DNA synthesis examined by thymidine- ${ }^{3} \mathrm{H}$ pulse labeling was not stimulated during avidin induction. Hydroxyurea (an inhibitor of DNA synthesis) and colchicine (a mitotic inhibitor) did not prevent induction. Studies utilizing uridine- ${ }^{3} \mathrm{H}$ pulses showed an effect on rapdly labeled nuclear RNA coincident with induction. Nuclear RNA polymerase activity increased before avidin induction. Since avidin was the only new protein synthesized in response to progesterone, the early stimulation of nuclear RNA synthesis and RNA polymerase activity would suggest a mechanism of action for this steroid at the transcription level of protein synthesis.
\end{abstract}

This work was presented at the Fifty-ninth Annual Meeting of the American Society for Clinical Investigation, Atlantic City, N. J. 1 May 1967.

Received for publication 26 May 1967 and in revised form 26 June 1967.

\section{INTRODUCTION}

There is little doubt that steroid hormones play a major role in regulation of tissue growth and functional differentiation, and their marked effects on protein synthesis have been discussed in numerous reviews (1-3). The precise mechanism of this regulation is still open to dispute $(4,5)$. Steroids could act either on nuclear transcription of the genetic message, at cytoplasmic sites to regulate translational expression of existing message into protein end products, or both. Present model systems such as the estrogen stimulation of the immature rat uterus (6), the androgen growthpromoting activity for male accessory sex glands $(7)$, and glucocorticoid effects on rat liver $(8,9)$ have firmly established the role of steroids in initiating and controlling protein synthesis. However, the actual step in protein synthesis that is primarily influenced is unclear because of the "mass" stimulation of synthesis of many proteins, enzymes, polymerases, DNA, and all RNA fractions. We shall present a series of studies on the mechanism of action of a steroid hormone in a system more specific and simple than many now available. In the chick oviduct, a single hormone, progesterone, induces synthesis of a single specific protein, avidin.

Hormonal induction of proteins in the chick oviduct has been previously reported (10). Estrogens cause a marked increase in oviduct weight in newborn and older chicks (11) and stimulate increases in tissue levels of major egg white proteins such as ovalbumins and lysozyme. However, in the estrogen-stimulated chick oviduct, one major 
protein, avidin, does not appear until a single dose of progesterone is administered. We have recently reported induction of avidin synthesis in minced oviduct in vitro with progesterone in tissue culture medium (12). We cannot prove that avidin is the only protein synthesized after progesterone but, since all other known oviduct proteins appear to be under estrogen control, the response is certainly relatively specific. Therefore, changes in nucleic acid metabolism in the oviduct after progesterone administration and before induction of avidin synthesis may be directly related to the mechanism of the induction.

\section{METHODS}

Materials. Progesterone was obtained from Nutritional Biochemicals Corporation, Cleveland, Ohio, and diethylstilbestrol was obtained from Merck \& Co., Rahway, N. J. Progesterone- ${ }^{-} \mathrm{H}$ (10 c/mmole) was obtained from New England Nuclear Corp., Boston, Mass., and chromatographed before use. Uridine- ${ }^{8} \mathrm{H}(11.9 \mathrm{c} / \mathrm{mmole})$, thymidine- ${ }^{-} \mathrm{H}$ ( $\left.6.7 \mathrm{c} / \mathrm{mmole}\right)$, lysine- ${ }^{8} \mathrm{H}(16.3 \mathrm{mc} / \mathrm{mmole})$, and leucine- ${ }^{8} \mathrm{H}$ ( $\left.5 \mathrm{c} / \mathrm{mmole}\right)$ were also obtained from New England Nuclear Corp. ${ }^{3} \mathrm{H}$-labeled uridine triphosphate (UTP) and cytidine triphosphate (CTP) were obtained from Schwarz Bio Research Inc., Orangeburg, $\mathrm{N}$. J. $d$-Biotin-carboxyl- ${ }^{14} \mathrm{C}(105 \mu \mathrm{c} / \mathrm{mmole})$ was obtained from Hoffman-LaRoche, Inc., Nutley, N. J. Avidin, calf thymus DNA, RNase, and DNase were purchased from Worthington Biochemical Corporation, Freehold, N. J. Herring sperm DNA and unlabeled CTP, adenosine triphosphate (ATP), and guanosine triphosphate (GTP) were obtained from Calbiochem, Los Angeles, Calif. NCS solubilizer was obtained from NuclearChicago Corporation, Chicago, Ill. Cycloheximide, actinomycin D, and 5-fluorouracil were obtained from National Cancer Chemotherapy Service Center, NIH, Bethesda, Md.

In vivo studies. In vivo avidin studies were carried out on immature female Rhode Island Red Chicks. Diethylstilbestrol [DES $(5 \mathrm{mg})$ ] was administered to 4day old chicks for 12-18 days. When hormonally immature oviduct was needed, no estrogen was administered. Progesterone was always given as a single dose at zero time. The animals were sacrificed at the indicated times, and the magnum portions of the oviducts were removed and homogenized at $4^{\circ} \mathrm{C}$ with 16 strokes of a motor-driven Teflon pestle in 6 volumes of. Buffer A $\left(0.07 \mathrm{M} \mathrm{KCl}, 0.004 \mathrm{M} \mathrm{MgCl}_{2}, 0.07\right.$ м $\mathrm{NaCl}, 0.02$ м sodium phosphate buffer, $\mathrm{pH} 7.1$ ). The homogenate was centrifuged at $5000 \mathrm{~g}$ for $30 \mathrm{~min}$, and the supernatant was centrifuged at $105,000 \mathrm{~g}$ for $2 \mathrm{hr}$. Avidin was measured in aliquots of the supernatant. For studies on nuclear RNA polymerase, nuclei were isolated as described below.

In vitro studies. Chicks were treated with DES for 12-18 days as above. The oviduct from each chick was removed, finely minced at $4^{\circ} \mathrm{C}$, and weighed. One-half the tissue served as a control, and the remainder was incubated with $5-10 \mu \mathrm{g}$ progesterone in $1 \mathrm{ml}$ of biotin-free 199 medium (N.I.H.) at $38^{\circ} \mathrm{C}$ in a Dubnoff metabolic shaker under $95 \% \quad \mathrm{O}_{2}-5 \% \quad \mathrm{CO}_{2}$ gas mixture. Crystalline penicillin G $(35 \mu \mathrm{g} / \mathrm{ml})$ and streptomycin $(50 \mu \mathrm{g} / \mathrm{ml})$ were added. Experiments were terminated by freezing, and the tissue and medium were homogenized in Buffer A as above and analyzed for avidin. For studies on nuclear RNA, nuclei were isolated as described below.

Avidin determination. Unless otherwise indicated, avidin was determined in all subsequent studies by the method of Korenman and O'Malley (13). The unknown $105,000 \mathrm{~g}$ soluble tissue fraction was reacted with an excess of $d$-biotin labeled with ${ }^{14} \mathrm{C}$ in the carboxyl group. Biotin is known to have a specific binding affinity for avidin. After a short incubation at room temperature, bentonite was added, binding the avidin nonspecifically. The avidin ${ }^{-14} \mathrm{C}$-biotin complex, bound to bentonite, was then pipetted onto a Millipore filter, washed with $0.2 \mathrm{M}$ $\left(\mathrm{NH}_{4}\right)_{2} \mathrm{CO}_{3}$ buffer, and the ${ }^{14} \mathrm{C}$ was counted in Bray's solution. No unbound biotin- ${ }^{14} \mathrm{C}$ remained on the filter. The blank of the method was zero and the sensitivity was $0.01 \mu \mathrm{g}$ avidin per sample. For convenience, avidin was expressed in the following studies as micrograms per gram of oviduct tissue, but the results were almost identical when expressed as per milligram of oviduct soluble protein.

Ovalbumin and lysozyme assay. Ovalbumin was measured as described by Kabat and Mayer (14) by quantitative immune precipitation. Agar gel diffusion studies using Ouchterlony plates showed that the bulk of precipitating protein was identical with the ovalbumin precipitin line of identity. Lysozyme was assayed by a modification of the method of Litwack (15).

Labeled amino acid incorporation into protein. An aliquot of the $105,000 \mathrm{~g}$ supernatant from in vitro incubated oviduct mince was precipitated with 10 volumes of $10 \%$ cold trichloroacetic acid (TCA) and allowed to stand at least $1 \mathrm{hr}$ at $4^{\circ} \mathrm{C}$. The suspension was centrifuged and washed twice with 10 volumes of $5 \%$ TCA. The precipitate was suspended in 3-5 $\mathrm{ml}$ of $5 \%$ TCA and heated for $30 \mathrm{~min}$ at $90^{\circ} \mathrm{C}$ in a water bath to hydrolyze RNA and to free acyl-bound amino acids. The solution was centrifuged and the supernatant discarded. The pellet was washed with $95 \%$ ethanol twice, ethanol:chloroform: ether $(1: 2: 1)$, and ether. The precipitate was mixed with $0.05 \mathrm{ml}$ of $\mathrm{H}_{2} \mathrm{O}$ and $1 \mathrm{ml}$ of NCS solubilizer, allowed to stand overnight at room temperature, and then counted in toluene-phosphor scintillation liquid. Corrections were made for quenching. Similar aliquots of 105,$000 \mathrm{~g}$ supernatant were analyzed for total protein by the method of Lowry, Rosenbrough, Farr, and Randall (16).

Estimation of DNA synthesis. The rate of DNA synthesis was determined utilizing pulses of thymidine- ${ }^{8} \mathrm{H}$. $10 \mu \mathrm{c}$ of thymidine- ${ }^{-3} \mathrm{H}$ (6.7 c/mmole) was added for $4 \mathrm{hr}$ to the oviduct incubates in thymidine-free medium at various times over the course of a $48 \mathrm{hr}$ experiment. Each pulse was stopped by freezing. The minces were washed with fresh 199 medium, homogenized in Buffer A, and 1 mg of cold DNA (herring sperm) carrier was added; 
4 volumes of $10 \%$ TCA were added and allowed to stand for $4 \mathrm{hr}$ at $4^{\circ} \mathrm{C}$. The precipitate was centrifuged and washed three times with $5 \%$ TCA (containing unlabeled thymidine, $200 \mu \mathrm{g} / \mathrm{ml}$ ). The pellet was then washed three times with ether: ethanol $(1: 3) .50 \mu \mathrm{l}$ of $\mathrm{H}_{2} \mathrm{O}$ was added with $1 \mathrm{ml}$ of NCS solubilizer to the precipitate, and the mixture was allowed to hydrolyze at room temperature for $24 \mathrm{hr}$. Aliquots were counted in toluene-phosphor and corrections for quenching were made. DNA mass determinations were carried out according to the method of Burton (17) and read against herring sperm DNA standard.

Isolation of oviduct nuclei. Oviduct was washed and suspended in $5 \mathrm{ml}$ of homogenizing solution, $0.32 \mathrm{M} \mathrm{su}-$ crose, $0.001 \mathrm{M} \mathrm{MgCl}_{2}, 0.004 \mathrm{M} \mathrm{KH}_{2} \mathrm{PO}_{4}, 0.0004 \mathrm{M} \mathrm{K}_{2} \mathrm{HPO}_{4}$, $\mathrm{pH}$ 6.7. All subsequent procedures were carried out at $4^{\circ} \mathrm{C}$. Homogenization was performed in a hand-held glass homogenizer with a motor-driven Teflon pestle. The homogenate was then passed through one layer of flannelette cloth after dilution with an equal volume of $0.05 \mathrm{M}$ Tris- $\mathrm{HCl}, 0.005 \mathrm{~m}$ mercaptoethanol, $\mathrm{pH}$ 7.6. The filtrate was centrifuged at $600 \mathrm{~g}$ for $20 \mathrm{~min}$. The pellet was resuspended in $25 \mathrm{ml}$ of the homogenizing solution and recentrifuged three times at $800 \mathrm{~g}$ for $10 \mathrm{~min}$. The resulting pellet was suspended in $4.5 \mathrm{ml}$ of the homogenizing solution and then mixed with $24 \mathrm{ml}$ of $2.39 \mathrm{M}$ sucrose $0.001 \mathrm{M} \mathrm{MgCl}_{2}, 0.0035 \mathrm{M} \mathrm{K}_{2} \mathrm{HPO}_{4}, 0.0007$ м ATP, pH 6.7, and centrifuged for $90 \mathrm{~min}$ at $50,000 \mathrm{~g}$ in an SW 25.1 Head, in the Spinco Model L Centrifuge. RNA, protein, and DNA determinations were carried out on each nuclear preparation to confirm purity and homogeneity between samples. Aliquots of nuclei were analyzed for in vitro incorporation of uridine $-{ }^{8} \mathrm{H}$ into nuclear RNA or resuspended in 1-2 $\mathrm{ml}$ of $0.05 \mathrm{M}$ Tris$\mathrm{HCl}, 30 \%$ glycerol ( $\mathrm{v} / \mathrm{v}), 0.001 \mathrm{M}$ mercaptoethanol, then aliquoted and frozen in solid carbon dioxide-ethanol and stored at $-20^{\circ} \mathrm{C}$ for use in RNA polymerase assay.

Nuclear RNA isolation and measurements. Nuclei were prepared from oviduct mince incubated in vitro by the procedure described above. The nuclei were washed in homogenizing solution, and aliquots were solubilized with $0.5 \mathrm{ml}$ of NCS solubilizer and counted. An aliquot of nuclei was then mixed with $3 \mathrm{ml}$ of $10 \%$ TCA and allowed to sit at $4^{\circ} \mathrm{C}$ for $1 \mathrm{hr}$. The precipitate was washed twice with $10 \% \mathrm{TCA}$ and then centrifuged. The precipitate was then washed with cold $95 \%$ ethanol, and then with ether. The pellet was suspended in $1 \mathrm{ml}$ of $5 \%$ TCA and heated at $90^{\circ} \mathrm{C}$ for $30 \mathrm{~min}$, with occasional stirring. The suspension was centrifuged and the soluble material saved; the procedure was repeated, and the soluble extracts were combined. Aliquots were again taken for counting, and the remainder was analyzed for RNA by an orcinol method (18).

Assay of RNA polymerase. The complete reaction mixture usually contained 0.05 mmole of Tris-maleate, $\mathrm{pH} 7.8,0.25 \mu$ mole of unlabeled ATP, GTP, and CTP, and $1.0 \mu \mathrm{c}$ of $\mathrm{UTP}-{ }^{8} \mathrm{H}(2.3 \mathrm{c} / \mathrm{mmole}), 2.0 \mu$ moles of $\mathrm{MnCl}_{2}$, and $2.0 \mu$ moles of mercaptoethanol. The nuclei were added in $0.025-0.1 \mathrm{ml}$ volumes corresponding to 10 $100 \mu \mathrm{g}$ of DNA. Ammonium sulfate ( $\mathrm{pH} 7.8$ ) was added to a final concentration of $0.375 \mathrm{M}$ when the high ionic assay was performed. The final volume was $1.0 \mathrm{ml}$, and the tubes were incubated at $38^{\circ} \mathrm{C}$ for $15 \mathrm{~min}$. The reaction was stopped by adding cold $7 \%$ perchloric acid to a final concentration of $2 \%$. Bovine serum albumin, 0.5 mg, was added as "carrier." All subsequent procedures were then carried out at $4^{\circ} \mathrm{C}$. The tubes were centrifuged at $10,000 \mathrm{~g}$. The precipitates were resuspended in $1 \%$ perchloric acid and recentrifuged three times. The precipitate was then washed with $95 \%$ ethanol, $0.02 \mathrm{M}$ potassium acetate, $\mathrm{pH}$ 7.2. The final precipitate was dissolved in $0.5 \mathrm{ml}$ of NCS solubilizer and counted. The results are expressed as cpm of UTP- ${ }^{8} \mathrm{H}$ incorporated into the acid insoluble product per $100 \mu \mathrm{g}$ of DNA in the nuclear suspension, although it is assumed that the precursor is present as uridine monophosphate (UMP) in RNA. Four samples were used for each determination. Standard errors of the mean were calculated in certain experiments. All subsequent experiments have been repeated on at least three separate occasions.

\section{RESULTS}

In vitro induction of avidin synthesis. A typical in vitro avidin induction curve is shown in Fig. 1. Avidin synthesis was first noted at $6 \mathrm{hr}$ and reached a maximum between 48 and $72 \mathrm{hr}$. Flasks occasionally became infected after $96 \mathrm{hr}$ of incubation, so the experiments were generally terminated at $48-72 \mathrm{hr}$. Tissue levels at zero time were unmeasurable $(<0.05 \mu \mathrm{g}$ of avidin/g of oviduct) by the biotin- ${ }^{14} \mathrm{C}$ binding assay. Therefore, the minces synthesized at least 100 times as much avidin as is present at zero time over the course of the incubation. We have previously reported that base line avidin synthesis does occur over the course of the incubation under certain conditions in flasks that contain no progesterone (12). In all subsequent studies, control minces synthesized insignificant amounts of avidin. Homogenates of oviduct did not synthesize avidin.

Specificity of in vitro induction in chick oviduct mince. Fig. 2 demonstrates the specificity of this induction system. No increase in other major oviduct proteins such as ovalbumins or lysozyme occurred during the incubation. We cannot absolutely rule out induction of some unknown oviduct protein. However, general protein synthesis, measured by successive pulses of amino acids- ${ }^{3} \mathrm{H}$ into TCA-precipitable protein, showed a progressive fall over the course of the incubation. These events are in contrast to the increased rate of avidin synthesis occurring concomitantly.

Rate of new DNA synthesis during the induction. To determine whether DNA synthesis or 


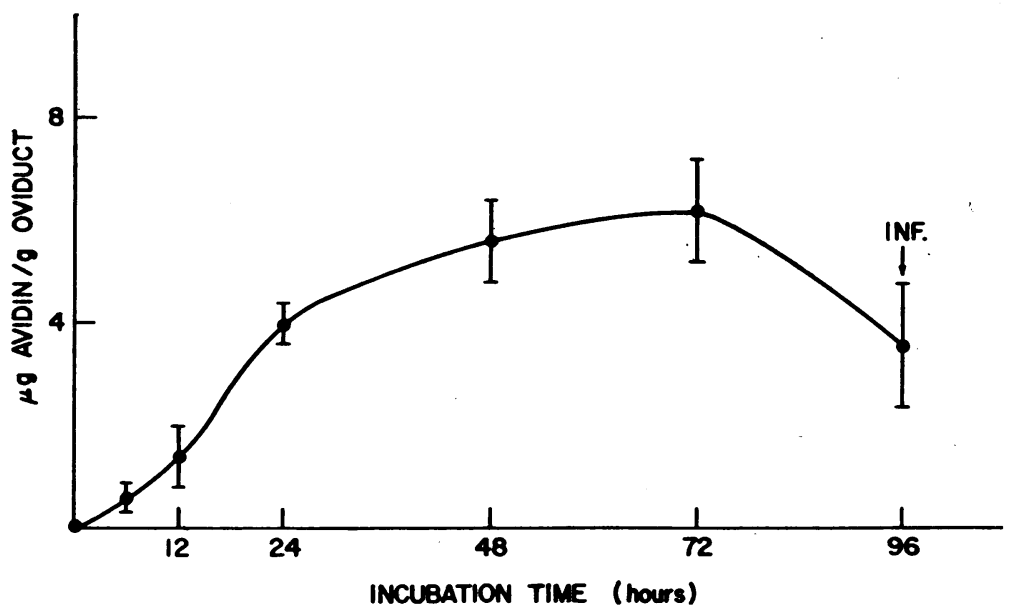

FIGURE 1 In vitro avidin induction curve. Progesterone ( $5 \mu \mathrm{g}$ ) was added at zero time to minced, weighed oviduct in $1 \mathrm{ml}$ of 199 tissue culture medium (N.I.H.) and incubated at $38^{\circ} \mathrm{C}$ for $96 \mathrm{hr}$ under $95 \% \mathrm{O}_{2}-5 \% \mathrm{CO}_{2}$ in a Dubnoff metabolic incubator. Incubation flasks were frozen at the indicated times and assayed for avidin. Each point represents the mean $\pm \mathrm{SE}$ of six oviducts analyzed separately. Infection (INF) occasionally occurred at this time point.

replication was a necessary prerequisite for avidin induction, the minces were pulsed for $4 \mathrm{hr}$ with thymidine $-{ }^{3} \mathrm{H}$ at various intervals throughout the incubation. Results are illustrated in Fig. 3. Progesterone did not stimulate thymidine- ${ }^{3} \mathrm{H}$ incorporation into DNA during the induction of avidin. The high rate of DNA synthesis seen early in the incubation was secondary to previous estrogen administration, and the decrease in rate of new DNA synthesis also occurred in oviduct incubates in the absence of progesterone.

Inhibitors of DNA synthesis and mitosis.-The presence of $0.001 \mathrm{~m}$ hydroxyurea, a known specific inhibitor of DNA synthesis, did not significantly affect progesterone induction of avidin synthesis (Fig. 4). 0.001 m hydroxyurea in this system decreased thymidine- ${ }^{3} \mathrm{H}$ incorporation into DNA $55-63 \%$ over controls at this concentration yet did not affect RNA or general protein synthesis. Addition of colchicine $(25 \mathrm{~m} \mu \mathrm{g} / \mathrm{ml})$ to the incubation medium also had no effect on the induction process. Higher concentrations of colchicine in-

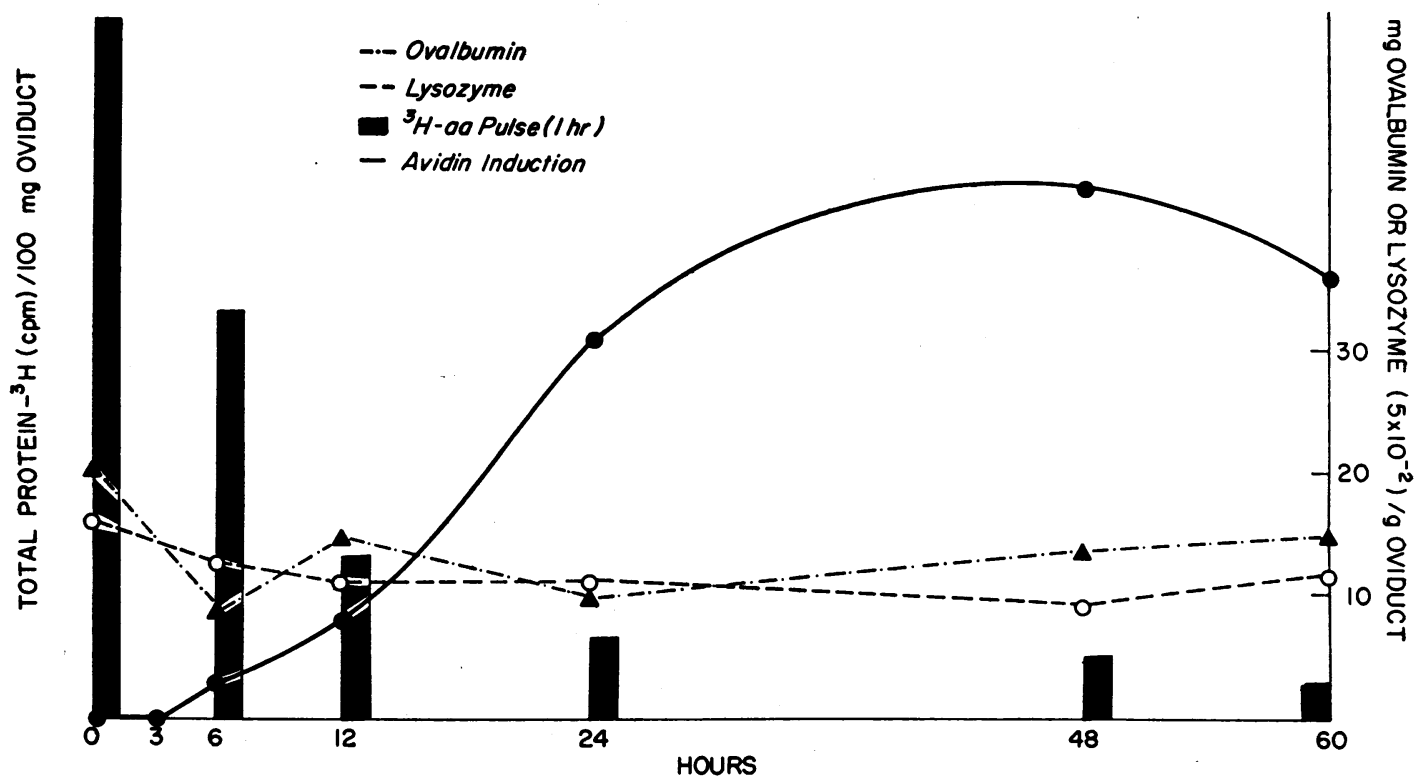

FIGURE 2 Levels of ovalbumin, lysozyme, and general protein synthesis during the course of a normal avidin in vitro induction as described in Fig. 1. Ovalbumin and lysozyme values represent the mean of six samples. Bars represent the average incorporation ( $\mathrm{six}$ samples) of tritium $\left({ }^{8} \mathrm{H}\right.$-amino acids) into TCA-precipitable protein after a $1 \mathrm{hr}$ pulse of $10 \mu \mathrm{c}$ of $1 \mathrm{ysine}-{ }^{8} \mathrm{H}(16.3 \mathrm{mc} / \mathrm{mmole})$. 


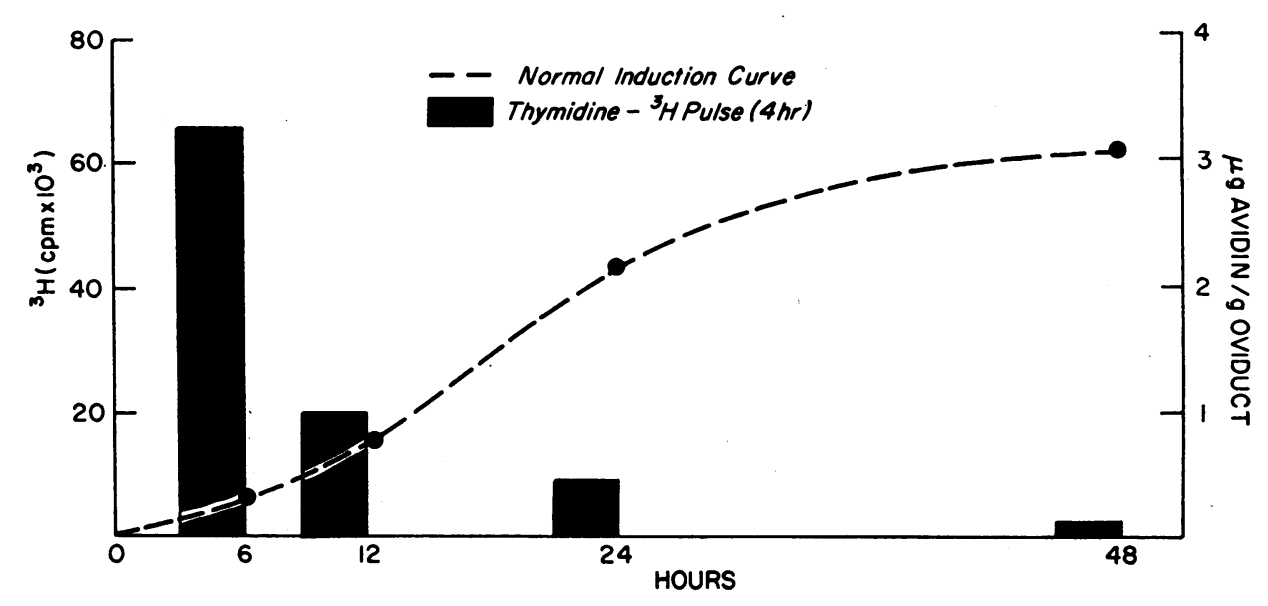

FIGURE 3 Rate of incorporation of thymidine into DNA during in vitro induction of avidin. $10 \mu \mathrm{c}$ of thymidine $-^{8} \mathrm{H}(6.7 \mathrm{c} / \mathrm{mmole})$ were added to the incubation flasks for $4 \mathrm{hr}$ during the periods indicated. Pulses were terminated by freezing. Bars represent the mean of six samples in a typical experiment.

hibited both RNA and protein synthesis. Pretreatment of the tissue with hydroxyurea or colchicine for $4 \mathrm{hr}$ before addition of progesterone also did not inhibit new avidin synthesis.

Inhibitors of RNA and protein synthesis. Fig. 5 shows the results of a $48 \mathrm{hr}$ incubation with progesterone and various inhibitors added at zero time. Addition of actinomycin D $(10 \mu \mathrm{g} / \mathrm{ml})$ caused a $70 \%$ inhibition of avidin synthesis without inhibition of general protein synthesis as mea-

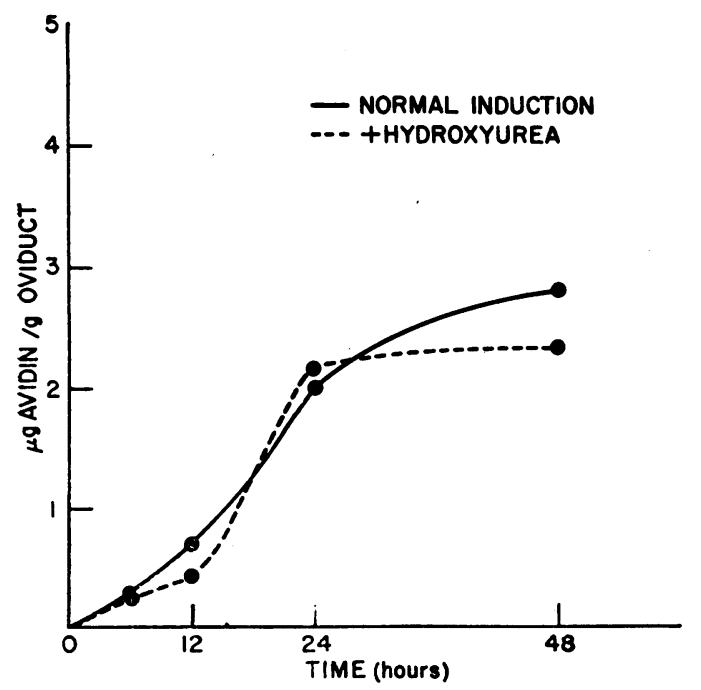

Figure 4 Effect of $0.001 \mathrm{M}$ hydroxyurea on avidin induction. Incubation conditions are the same as in Fig. 1. Each point represents the mean of six samples analyzed sepa. rately. sured by incorporation of labeled amino acids into TCA-precipitable material. The induction process was dependent on new protein synthesis, since addition of cycloheximide $(10 \mu \mathrm{g} / \mathrm{ml})$ at any time during the incubation prevented the induction completely. This concentration of cycloheximide was sufficient to inhibit lysine- ${ }^{3} \mathrm{H}$ incorporation into TCA-preciptable material by at least $90 \%$. Addition of 5-fluorouracil $(100 \mu \mathrm{g} / \mathrm{ml})$ to the incubation did not significantly affect avidin synthesis.

Rapidly labeled nuclear RNA. The rate of

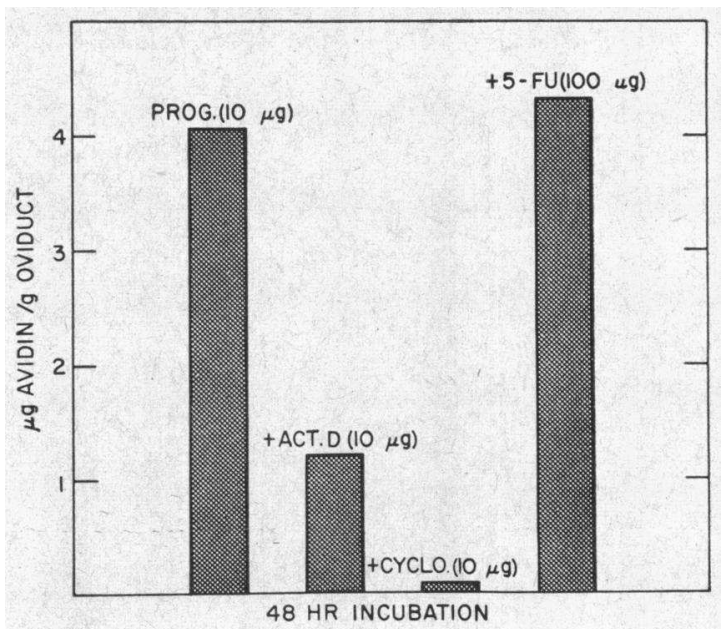

Figure 5 Effect of actinomycin D $(A C T . D)$, cycloheximide (CYCLO.), or 5-fluorouracil $(5-F U)$ on avidin synthesis. Progesterone (PROG.) was added at zero time and incubated as in Fig. 1. Bars represent mean of five oviducts analyzed separately. 


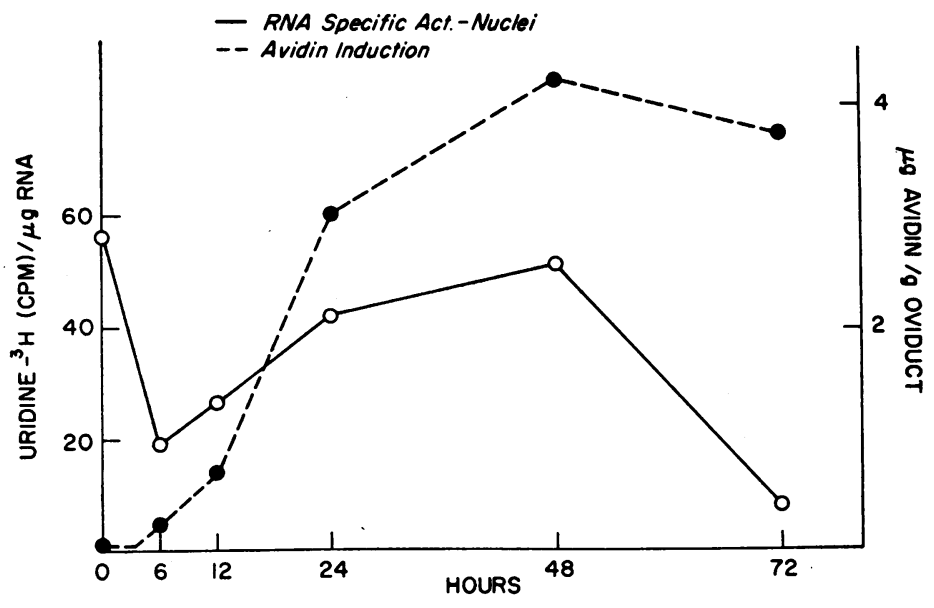

Figure 6 Changes in rapidly labeled nuclear RNA during avidin induction by progesterone. Incubation conditions are the same as in Fig. 1. The incubates were pulsed for $20 \mathrm{~min}$ with $10 \mu \mathrm{c}$ of uridine ${ }^{3} \mathrm{H}(11.9 \mathrm{c} /$ mmole), terminated by freezing at the points indicated, and nuclei were extracted and analyzed as in text. Each point represents the mean of five oviduct nuclear preparations analyzed separately.

synthesis of rapidly labeled, oviduct nuclear RNA was studied at various times during in vitro avidin induction utilizing 20-min pulses of tritiated or ${ }^{14} \mathrm{C}$-uridine. Extraction and sucrose density purification of intact nuclei were carried out, and nuclear RNA specific activity was determined. A decrease $(>50 \%)$ at $2-6 \mathrm{hr}$ was consistently observed, followed by a rise in nuclear RNA specific activity before avidin induction (Fig. 6). The rise reached a maximum between 24 and $48 \mathrm{hr}$ and generally did not exceed the levels observed at zero time. Controls showed neither the fall nor rise in nuclear RNA seen in the minces incubated with progesterone. A fall in the specific activity of rapidly labeled nuclear RNA was noted after 48 $\mathrm{hr}$ which coincided temporally with cessation of avidin synthesis. No change was noted in total oviduct RNA by either mass or precursor incorporation methods.
Nuclear RNA polymerase activity after progesterone administration to estrogen pretreated chicks. The following studies on RNA polymerase were carried out with purified nuclei from animals sacrificed at various times after a single dose of progesterone $(5 \mathrm{mg}$ in propylene glycol carrier) in vivo at zero time.

An effect on RNA polymerase activity of isolated nuclei was noted which was quite similar to that seen with rapidly labeled nuclear RNA (Fig. 7). A fall from zero time levels occurred $2 \mathrm{hr}$ after progesterone administration followed by a rise before induction of avidin synthesis. Ammonium sulfate enhanced in vitro polymerase activity threefold in our system but never altered the shape of the $48 \mathrm{hr}$ progesterone response curve. Control chicks, not receiving progesterone, showed no changes in RNA polymerase activity. It was suspected that the initial high levels of nuclear RNA

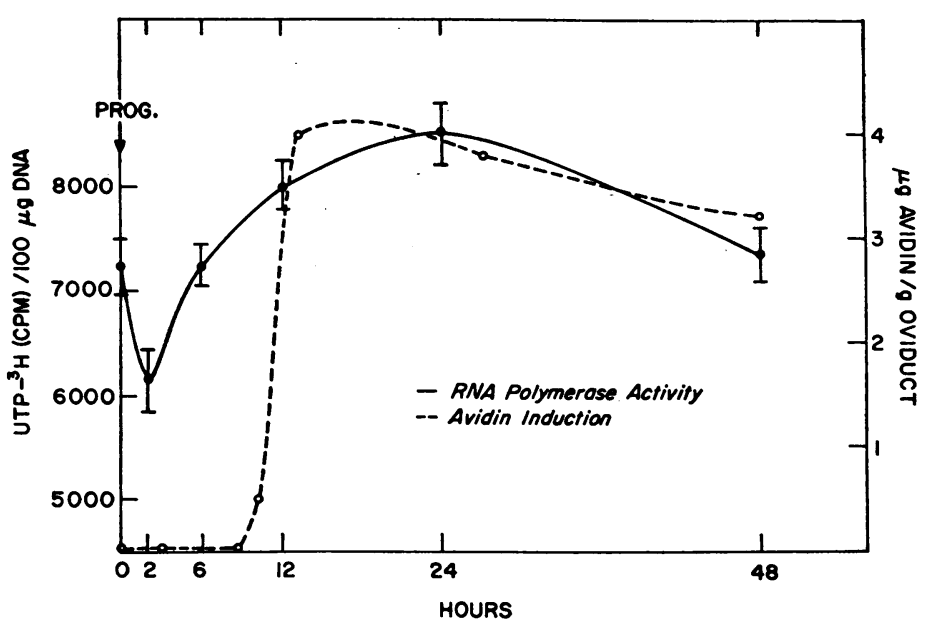

FigUre 7 Oviduct nuclear RNA polymerase activity after a single in vivo injection of progesterone to estrogen-pretreated chicks. Progesterone $(5 \mathrm{mg}$, s.c. in propylene glycol) was given at zero time, and groups of 10 oviducts were pooled and analyzed for polymerase and avidin at the indicated times. Each point represents the mean $\pm \mathrm{SE}$ of six determinations on each pool. 


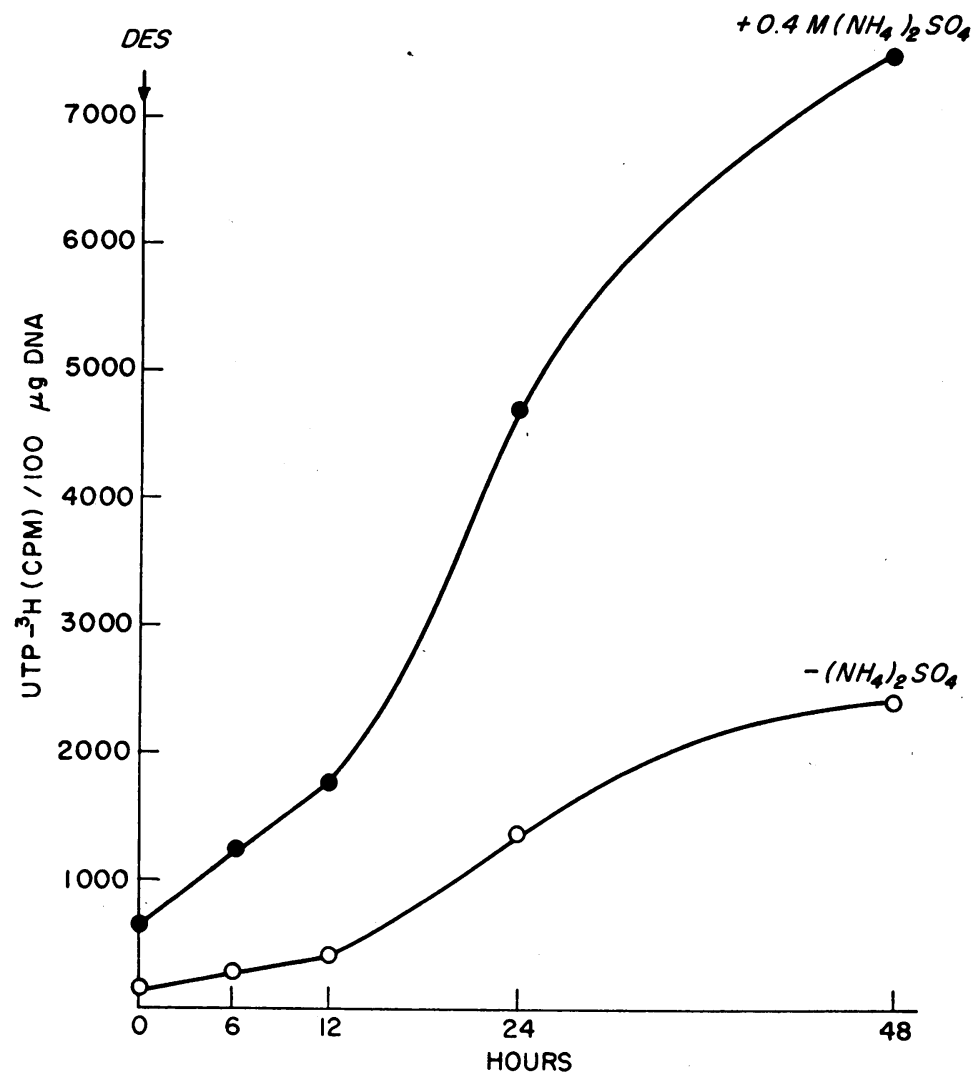

FIGURE 8 Oviduct nuclear RNA polymerase activity after a single in vivo injection of diethylstilbestrol (DES) to hormonally unstimulated chicks. Protocol was as in Fig. 7, but in vitro assays were carried out both in the presence and absence of $0.375 \mathrm{M}\left(\mathrm{NH}_{4}\right)_{2} \mathrm{SO}_{4}$.

labeling and polymerase activity were secondary to previous in vivo diethylstilbestrol administration.

Nuclear RNA polymerase activity after diethylstilbestrol administration to immature chicks. A single $5 \mathrm{mg}$ dose of DES at zero time resulted in prolonged stimulation of oviduct nuclear RNA polymerase (Fig. 8). The maximum rate of increase was between 12 and $24 \mathrm{hr}$, and the stimulatory effect had not ceased by $48 \mathrm{hr}$ after injection of the estrogen. A similar response curve was noted in the presence or absence of ammonium sulfate, although the higher salt concentration enhanced assay activity at all time points.

Nuclear RNA polymerase activity after progesterone administration to immature chicks. Progesterone administration to the immature chick that had not previously been stimulated with estrogens caused a small amount of avidin synthesis. If the avidin synthesized is calculated on a basis of specific activity (micrograms of avidin per gram of oviduct), the response of the immature gland ( $5 \mathrm{mg}$ ) is comparable to that of the estrogenstimulated gland ( $>1500 \mathrm{mg}$ ). Fig. 9 shows the marked rise in RNA polymerase activity which follows a single injection of progesterone $(5 \mathrm{mg}$ ) at zero time. The rise begins at $5-10 \mathrm{hr}$ and peaks. at 24-26 hr. Avidin induction follows the rise in polymerase.

\section{DISCUSSION}

The chick oviduct is illustrated in Fig. 10. After the ovary releases the egg, it enters the infundibulum and is passed into the magnum where the major oviduct proteins, ovalbumins, lysozyme, and avidin are secreted into the developing egg. The immature oviduct grows over 1000 -fold in $4 \mathrm{wk}$ under estrogenic stimulation, enhancing synthesis of all known oviduct proteins except avidin. We have previously reported that avidin only appears in response to a progestational or antiestrogenic hormone (19). The chick oviduct, then, appears to be an endocrine target organ well suited to study both estrogen-stimulated protein synthesis, growth, and differentiation, and the more specific response of avidin to progesterone.

The present studies have demonstrated the syn- 


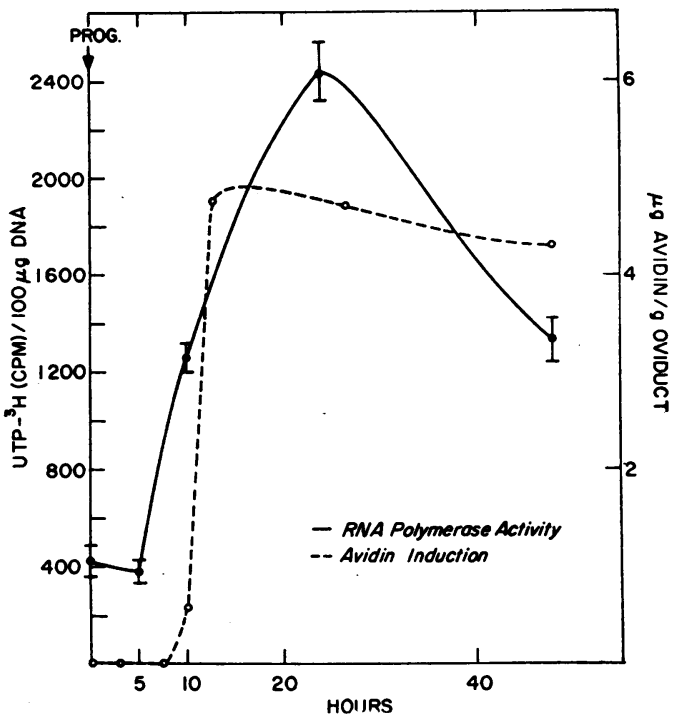

FIgURe 9 Oviduct nuclear RNA polymerase activity after a single in vivo injection of progesterone to immature chicks not previously treated with estrogens. Protocol is the same as in Fig. 7.

thesis of avidin in minced estrogen-treated oviduct after in vitro incubation with progesterone in tissue culture medium. The induction of avidin appears to be relatively specific, since total protein synthesis, ovalbumins, and lysozyme fail to show a similar response. Previous studies from this laboratory have confirmed the identity of the avidin incubation product by disc gel electrophoresis, antibody precipitation studies, or assay of biological activity utilizing binding to biotin $-{ }^{14} \mathrm{C}$ (12). Using labeled amino acids, we demonstrated a peak in the rate of synthesis of avidin-antiserum- precipitable protein at $12-24 \mathrm{hr}$ of incubation (12). These studies proved the actual induction of synthesis of new avidin protein. Avidin is a relatively stable protein with a $t_{1}$ of $5-6$ days in this system, and no changes in degradation were noted during the induction process.

The data presented in this paper would suggest that new DNA synthesis is not necessary for avidin induction. Progesterone does not stimulate thymidine- ${ }^{3} \mathrm{H}$ incorporation into DNA. Hydroxyurea, a specific inhibitor of DNA synthesis in animal cells, is thought to interfere with ribonucleotide (diphosphate) reduction $(20,21)$. This drug did not delay or inhibit avidin synthesis at a concentration that inhibited DNA synthesis by $63 \%$. Since some DNA synthesis still occurred, the data are only suggestive that this drug did not inhibit avidin induction. Similarly, colchicine, a cell mitotic inhibitor which has been reported to complex DNA template (22), had no effect on avidin synthesis at low concentrations. This finding is contrary to studies of Stockdale and Topper (23) on mouse mammary gland where insulinmediated DNA synthesis and mitosis must occur in the presence of hydrocortisone for prolactin to stimulate new casein synthesis. They proposed that cell division may make a cell especially susceptible to environmental factors (hormones) capable of eliciting changes in cell function. This hypothesis apparently does not directly apply to avidin induction but may be related to estrogenstimulated differentiation and induction of other oviduct proteins.

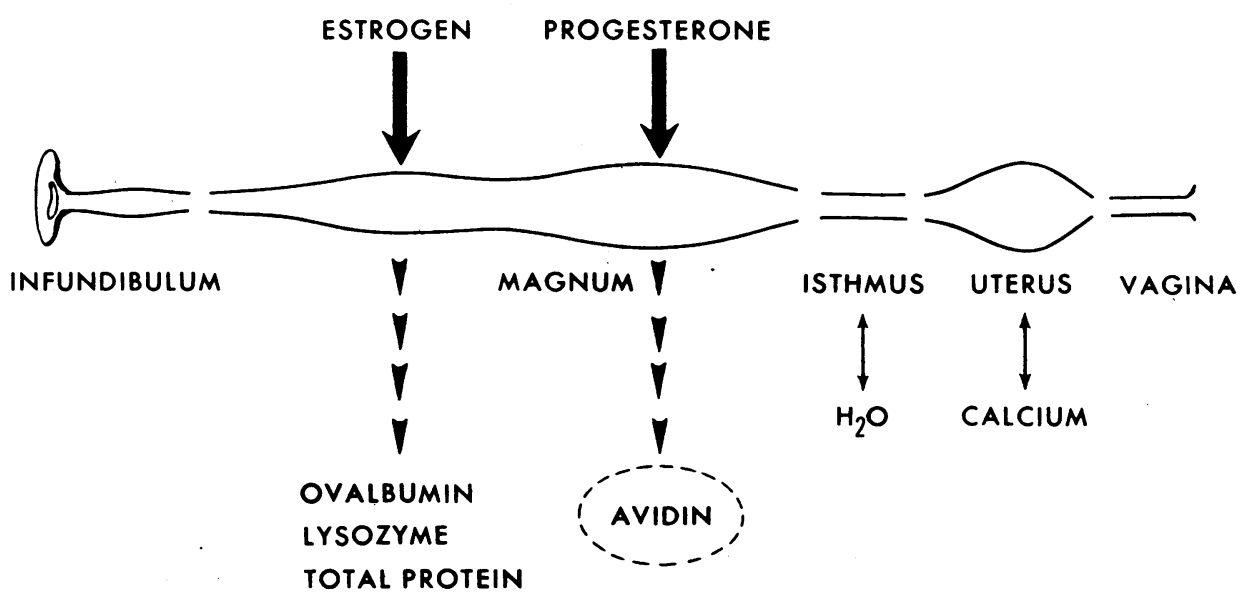

FIGURE 10 Diagram of functional segments of the chick oviduct. 
Cycloheximide, an antibiotic which is thought to inhibit protein synthesis in animal cells by blocking transfer of amino acids from soluble RNA (sRNA) to ribosomal polypeptide (24), inhibited avidin synthesis almost completely. This finding further confirms the fact that the induction is dependent on new protein synthesis.

Actinomycin D added at zero time effected 70$90 \%$ inhibition of avidin synthesis. This suggests, but does not prove, that new DNA-dependent RNA synthesis is specifically required for induction. At concentrations of actinomycin $\mathrm{D}$ which do not completely suppress RNA formation, ribosomal precursor RNA appears to be most sensitive to the antibiotic and sRNA least sensitive (25). Some caution should accompany interpretations of actinomycin $\mathrm{D}$ inhibition because numerous other effects have been noted with this antibiotic (26-28) in addition to its accepted inhibition of DNA-directed RNA synthesis.

We have observed that addition of actinomycin $\mathrm{D}$ to the in vitro oviduct incubations after $6 \mathrm{hr}$ led to a stimulation in the rate of avidin synthesis that could not be accounted for on the basis of product stabilization. A possible interpretation of this apparent "superinduction" would be that actinomycin D inhibits all messenger RNA (mRNA) synthesis and the avidin mRNA is relatively stable, while the mRNA for a labile cytoplasmic repressor is rapidly turning over. This theory of translational (cytoplasmic) derepression has been proposed as a mechanism for steroid regulation of protein synthesis in both in vivo (29) and in vitro systems (30). No other evidence to substantiate this concept exists in our studies.

No inhibition of avidin synthesis was seen with additions of 5-fluorouracil (5-FU) to the oviduct incubations. This drug is thought to be incorporated into RNA, thereby producing a defective message. Dorfman (31) has reported that 5-FU blocks androgenic but not estrogenic target organ stimulation in the mouse. In studies with $E$. coli, 5 -FU has caused the synthesis of inactive $\beta$-galactosidase without inhibition of protein synthesis (32). Since 5-FU did not inhibit avidin synthesis by our detection methods, we must postulate that either a messenger RNA is not necessary for avidin synthesis, or that a defective RNA produced did not direct the synthesis of an avidin molecule which was biologically inactive, relative to biotin binding.
Our studies which showed an early decrease in rapidly labeled nuclear RNA-specific activity followed by a rise before avidin induction suggested a primary nuclear transcriptional effect for progesterone. On the basis of our present data, it would be presumptuous to assume a simple stimulation of avidin mRNA synthesis by the steroid. It has been shown that the bulk of the rapidly labeled nuclear RNA (45s and 35sRNA) of animal cells is either ribosomal or ribosomal precursor RNA (33). The exact fate of rapidly labeled nuclear RNA is still in question $(34,35)$. Therefore, the final implications of the steroidmediated changes in rapidly labeled nuclear RNA cannot be stated with absolute certainty.

The studies on RNA polymerase after in vivo progesterone reported in this paper show an effect on the enzyme similar to that seen with rapidly labeled nuclear RNA. A brief fall in activity at $2 \mathrm{hr}$ after administration of the steroid is followed by a rise before avidin induction. The magnitude of this rise may be greater than one would expect if the induction involved only a single protein. This same type of response curve was seen in both rapidly labeled nuclear RNA and the polymerase enzyme responsible for its synthesis. This finding again points to a primary nuclear action for progesterone. The mechanisms involved in this early decrease and then rise in nuclear RNA synthesis and RNA polymerase are not yet elucidated. On purely theoretical grounds, we could postulate that progesterone is acting to repress genes involved in synthesizing estrogen-stimulated oviduct proteins while allowing synthesis of new RNA involved in production of avidin. Estrogen withdrawal cannot explain the initial drop in activity, because controls are unchanged and estrogen stimulation of RNA polymerase lasts at least $48 \mathrm{hr}$ after a single injection (Fig. 8). A similar fall before a rise in nuclear RNA labeling after hormone administration has been reported by other investigators $(36,37)$. It is unlikely that this initial drop in nuclear RNA labeling and polymerase activity could represent a sudden change in precursor pool size for the following reasons: (a) the results are identical using either labeled uracil, UTP, or CTP; (b) similar curves can be obtained in vitro or in vivo; $(c)$ early changes in RNA production have also been obtained using purified chromatin isolated at various times after progesterone administration and incubated in vitro 
with $E$. coli RNA polymerase and known amounts of precursor nucleotides (W. L. McGuire and B. W. O'Malley, unpublished data). We also cannot disprove the concept of two populations of oviduct cells, one of which responds to progesterone and one which is unresponsive or inhibited. Progesterone inhibition of cytoplasmic synthesis of all oviduct proteins except avidin could account for the initial fall in rapidly labeled nuclear RNA, but it would be unlikely.

The high values for nuclear RNA polymerase at zero time before progesterone administration were probably secondary to prior estrogenic stimulation. This hypothesis is confirmed by the data collected on hormonally immature chicks given a single dose of diethylstilbestrol. The oviduct nuclear RNA polymerase shows a tenfold rise in activity over a $48 \mathrm{hr}$ period. Furthermore, we have shown that progesterone administration to the immature chick can stimulate RNA polymerase without the benefit of prior estrogen administration. This dramatic stimulatory effect (Fig. 9) again supports the concept of a primary nuclear mechanism for progesterone induction of avidin synthesis.

Stimulation of RNA polymerase in various subcellular fractions by steroid hormones has been reported in male accessory sex tissues with androgens (38), in rat uterus with estrogens (39), and in rat liver after glucocorticoid administration (40). The implications of these steroid effects on RNA polymerase are obvious but not yet proven experimentally.

If the Jacob and Monod (41) theory were correct in animal cells, the steroid would combine allosterically with a nuclear repressor protein and thereby derepress (induce) a gene, allowing it to be transcribed by RNA polymerase into new mRNA and eventually translated at the ribosomal level into the end product of the gene. During this process, one might see both increased RNA polymerase activity and nuclear RNA synthesis (messenger RNA and ribosomal RNA) after introduction of the steroid and before appearance of the end product.

The actual mechanism of progesterone induction of avidin synthesis is not yet proven. Two major sites for hormonal regulation of protein synthesis now exist: at the transcriptional level in the nucleus or the translational level in the cytoplasm. We cannot rule out the possibility of some effect of progesterone on a cytoplasmic repressor. Furthermore, the inhibitory effect of actinomycin $\mathrm{D}$ when added to the incubation at zero time, the early changes in rapidly labeled nuclear RNA, and the early effect on nuclear RNA polymerase would suggest a mechanism of action for progesterone at the nuclear or transcription level of protein synthesis, resulting in transfer of the avidin message to the ribosomal level and eventuating in avidin synthesis. We would caution against an oversimplification of this interpretation until the methods become available in higher organisms for isolation of a purified RNA species capable of directing synthesis of a specific protein in a soluble ribosomal system.

\section{REFERENCES}

1. Tomkins, G. M., and E. S. Maxwell. 1963. Some aspects of steroid hormone action. Ann. Rev. Biochem. 32: 677 .

2. Tata, J. R. 1966. Hormones and the synthesis and utilization of ribonucleic acids. In Progress in Nucleic Acid Research and Molecular Biology. J. N. Davidson and W. E. Cohn, editors. Academic Press Inc., New York. 5: 191.

3. Williams-Ashman, H. G. 1965. New facets of the biochemistry of steroid hormone action. Cancer Res. 25: 1096.

4. Bonner, J. 1965. The template activity of chromatin. J. Cellular Comp. Physiol. 66(Suppl. 1) : 77.

5. Tomkins, G. M., L. D. Garren, R. R. Howell, and B. Peterkofsky. 1965. The regulation of enzyme synthesis by steroid hormones: the role of translation. J. Cellular Comp. Physiol. 66 (Suppl. 1) : 137.

6. Gorski, J., W. D. Noteboom, and J. A. Nicolette. 1965. Estrogen control of the synthesis of RNA and protein in the uterus. J. Cellular Comp. Physiol. 66 (Suppl. 1) : 91.

7. Williams-Ashman, H. G., S. Liao, R. L. Hancock, L. Jurkowitz, and D. A. Silverman. 1964. Testicular hormones and the synthesis of ribonucleic acids and proteins in the prostate gland. Recent Progr. Hormone Res. 20: 247.

8. Jervell, K. F. 1963. Early effects of glucocorticoids on ribonucleic acid and protein metabolism in rat liver. Acta Endocrinol. Suppl. 88: 3.

9. Garren, L. D., R. R. Howell, and G. M. Tomkins. 1964. Mammalian enzyme induction by hydrocortisone: the possible role of RNA. J. Mol. Biol. 9: 100.

10. Korenman, S. G., and B. W. O'Malley. Progesterone action: Regulation of in vivo and in vitro avidin biosynthesis by hen oviduct. Endocrinology. In press.

11. Brant, J. W. A., and A. V. Nalbandov. 1956. Role of sex hormones in albumin secretion by the oviduct of chickens. Poultry Sci. 35: 692.

12. O'Malley, B. W. 1967. In vitro hormonal induction of a specific protein (avidin) in chick oviduct. Biochemistry. 6: 2546.

Progesterone: Mechanism of Action 
13. Korenman, S. G., and B. W. O’Malley. 1967. Avidin assay. A new procedure suitable for tissue fractions. Biochim. Biophys. Acta. 140: 174.

14. Kabat, E. A., and M. M. Mayer. 1961. Estimation of antigens. In Experimental Immunochemistry. Charles C Thomas, Publisher, Springfield, Ill. 361.

15. Litwack, G. 1955. Photometric determination of lysozyme activity. Proc. Soc. Exptl. Biol. Med. 89: 401.

16. Lowry, O. H., N. J. Rosebrough, A. L. Farr, and R. J. Randall. 1951. Protein measurement with the Folin phenol reagent. J. Biol. Chem. 193: 265.

17. Burton, K. 1956. A study of the conditions and mechanism of the diphenylamine reaction for the colorimetric estimation of deoxyribonucleic acid. Biochem. J. $62: 315$.

18. Littlefield, J. W., E. R. Keller, J. Gross, and P. C. Zamecnik. 1955. Studies on cytoplasmic ribonucleoprotein particles from the liver of the rat. J. Biol. Chem. 217: 111.

19. O'Malley, B. W., W. L. McGuire, and P. A. Middleton. 1967. Structure-function relationships of various steroids relative to induction of a specific oviduct protein (avidin). Endocrinology. 81: 677.

20. Young, C. W., and S. Hodas. 1964. Hydroxyurea: Inhibitory effect on DNA metabolism. Science. 146: 1172.

21. Frenkel, E. P., W. N. Skinner, and J. D. Smiley. 1964. Studies on a metabolic defect induced by hydroxyurea. Cancer Chemotherapy Rep. 40: 19.

22. Ilan, J., and J. H. Quastel. 1966. Effects of colchicine on nucleic acid metabolism during metamorphosis of Tenebris molitor $\mathrm{L}$. and in some mammalian tissues. Biochem. J. 100: 448.

23. Stockdale, F. E., and Y. J. Topper. 1966. The role of DNA synthesis and mitosis in hormone-dependent differentiation. Proc. Natl. Acad. Sci. U. S. 56: 1283.

24. Ennis, H. L., and M. Lubin. 1964. Cycloheximide: aspects of inhibition of protein synthesis in mammalian cells. Science. 146: 1474.

25. Reich, E., and I. H. Goldberg. 1964. Actinomycin and nucleic acid function. In Progress in Nucleic Acid Research and Molecular Biology. J. N. Davidson and W. E. Cohn, editors. Academic Press Inc., New York. 3: 227.

26. Revel, M., H. H. Hiatt, and J. Revel. 1964. Actinomycin D: an effect on rat liver homogenates unrelated to its action on RNA synthesis. Science. 146: 1311.

27. Korn, D., J. J. Protass, and L. Leive. 1965. A novel effect of actinomycin D in preventing bacteriophage $\mathrm{T}_{4}$ maturation in Escherichia Coli. Biochem. Biophys. Res. Commun. 19: 473.
28. Laszlo, J., D. S. Miller, and K. S. McCarty, and P. Hochstein. 1966. Actinomycin D : inhibition of respiration and glycolysis. Science. 151: 1007.

29. Garren, L. D., R. R. Howell, G. M. Tomkins, and R. M. Crocco. 1964. A paradoxical effect of actinomycin D: the mechanism of regulation of enzyme synthesis by hydrocortisone. Proc. Natl. Acad. Sci. U.S. 52: 1121 .

30. Tomkins, G. M., E. B. Thompson, S. Hayashi, T. Gelehrter, D. Granner, and B. Peterkofsky. 1966. Tyrosine transaminase induction on mammalian cells in tissue culture. Cold Spring Harbor Symp. Quant. Biol. 31 : 349.

31. Dorfman, R. I. 1963. The antiandrogenic activity of 5-fluorouracil. Steroids. 2: 555.

32. Horowitz, J., J. J. Saukkonen, and E. Chargaff. 1958. Effect of 5-fluorouracil on a uracil requiring mutant of Escherichia coli. Biochim. Biophys. Acta. 29: 222.

33. Roberts, W. K., and J. F. E. Newman. 1966. Use of low concentrations of actinomycin $\mathrm{D}$ in the study of RNA synthesis in Ehrlich ascites cells. J. Mol. Biol. 20: 63 .

34. Henshaw, E. C., M. Revel, and H. H. Hiatt. 1965. A cytoplasmic particle bearing messenger ribonucleic acid in rat liver. J. Mol. Biol. 14: 241.

35. Shearer, R. W., and B. J. McCarthy. 1967. Evidence for ribonucleic acid molecules restricted to the cell nucleus. Biochemistry. 6: 283.

36. Widnell, C. C., and J. R. Tata. 1966. Additive effects of thyroid hormone, growth hormone and testosterone on deoxyribonucleic acid-dependent ribonucleic acid polymerase in rat-liver nuclei. Biochem. J. 98: 621 .

37. Weber, G., S. K. Srivastava, and R. L. Singhal. 1965. Role of enzymes in homeostasis. VII. Early effects of corticosteroid hormones on hepatic gluconeogenic enzymes, ribonucleic acid metabolism, and amino acid level. J. Biol. Chem. 240: 750.

38. Liao, S., K. R. Leininger, D. Sagher, and R. W. Barton. 1965. Rapid effect of testosterone on ribonucleic acid polymerase activity of rat ventral prostate. Endocrinology. 77: 763.

39. Gorski, J. 1964. Early estrogen effects on the activity of uterine ribonucleic acid polymerase. J. Biol. Chem. 239: 889 .

40. Lang, N., and C. E. Sekerkis. 1964. Stimulation of RNA-polymerase activity in rat liver by cortisol. Life Sci. Space Res. 3: 391.

41. Jacob, F., and J. Monod. 1961. Genetic regulatory mechanisms in the synthesis of proteins. J. Mol. Biol. $3: 318$. 